\title{
Immunological background for treatments with biologicals in CRSwNP
}

\section{Klimek*, J Hagemann, I Casper, T Huppertz, A Bedbrook and J Bousquet}

Centrum for Rhinology and Allergology Wiesbaden, Germany

\section{Abstract}

Background: Chronic rhinosinusitis (CRS) is a heterogeneous and multifactorial inflammatory disease of the nasal and paranasal mucosa. To date, no internationally standardized uniform classification has been developed for this disease.

Usually, a phenotype classification according to CRS with (CRSwNP) and without (CRSsNP) polyposis is performed. However, through a variety of studies, it has been shown that even within these phenotypes, different endotypes of CRS exist, each with a different underlying inflammatory pathophysiology. In this mini-review, we aim to outline the essential immunological processes in CRSwNP and to highlight the modern therapeutic options with biologics derived from this disease.

Methods: Current knowledge on the immunological and molecular processes of CRS, especially CRSwNP, was compiled by means of a structured literature review. Medline, PubMed, national/international trial and guideline registries as well as the Cochrane Library were all searched.

Results: Based on the current literature, the different immunological processes involved in CRS and nasal polyps were elaborated. Current studies on the therapy of eosinophilic diseases such as asthma and polyposis are presented and their results discussed.

Conclusion: Understanding the immunological basis of CRSwNP may help to develop new personalized therapeutic approaches using biologics. Currently, 2 biologics (dupilumab, omalizumab) have been approved for the therapy of CRSwNP (polyposis nasi) in Europe.

\section{More Information}

*Address for Correspondence: L Klimek, Centrum for Rhinology and Allergology Wiesbaden, Germany, An den Quellen 10 D-65183 Wiesbaden, Germany, Tel: 0049-611-308 6080; Fax: +49-611-308 608-255; Email: ludger.klimek@Allergiezentrum.org

Submitted: March 23, 2021

Approved: April 07, 2021 Published: April 08, 2021

How to cite this article: Klimek L, Hagemann J, Casper I, Huppertz T, Bedbrook A, et al. Immunological background for treatments with biologicals in CRSwNP. Arch Asthma Allergy Immunol. 2021; 5: 022-029.

\section{DOI: 10.29328/journal.aaai.1001026}

Copyright: (c) 2021 Klimek L, et al. This is an open access article distributed under the Creative Commons Attribution License, which permits unrestricted use, distribution, and reproduction in any medium, provided the original work is properly cited.

Check for updates

OPEN ACCESS

\section{Introduction}

The prevalence of chronic rhinosinusitis (CRS) in developed countries is approximately $10 \%-15 \%$ of the population, resulting in significant costs for healthcare systems and national economies $[1,2]$.

The diagnosis of CRS has traditionally been based on clinical parameters. Here, the presence of 2 major symptoms (facial/head pressure, nasal obstruction, hyposmia/anosmia, or purulent nasal secretion) or one major symptom and at least 2 minor symptoms (headache, fever, halitosis, cough, toothache, fatigue, and ear pressure) over a period of more than 12 weeks is required [3]. In addition, current guidelines require endoscopic and/or radiologic evidence of inflammatory tissue in addition to 2 major criteria $[1,3,4]$. Phenotype classification is based on endoscopic examination of the nasal cavity or imaging techniques. It divides CRS into chronic rhinosinusitis with nasal polyps (CRSwNP) and chronic rhinosinusitis without nasal polyps (CRSsNP).

However, CRSwNP and CRSsNP are not unitary syndromes because different pathomechanisms exist within these phenotypes, resulting in different forms of inflammation of the sinunasal mucosa. These are referred to as endotypes. In the future, this endotype classification could enable a targeted, pathophysiologically-based therapy for CRSwNP [5].

For this purpose, reliable and easy-to-determine biomarkers have to be developed [6].

\section{Immunology of nasal polyps}

CRSwNP is characterised, among other things, by a highly edematous stroma with subepithelial and perivascular 
infiltration of the inflammatory cells. Infiltration of activated T lymphocytes occurs in all subsets of paranasal sinus disease, but, in nasal polyps, different T lymphocyte subsets contribute [1]. In recent years, the T-cell subpopulations in chronic sinusitis and nasal polyposis have been well characterised, and their biological function determined.

In general, lymphocytes can be divided into a uniform B-lymphocyte population and various T-lymphocyte subsets. Divided into CD8 positive (CD8+) T suppressor cells and CD4+ T helper cells, CD4+ T cells are capable of differentiating into $\mathrm{T}$ helper (Th)1, Th2, Th9, Th17, Th22 and follicular Thelper (Tfh) effector cells, among others $[7,8]$. The balance between these T-helper subtypes is extremely important for the physiology of the mucosal immune system and can be altered by persistent inflammatory processes. In CRSwNP, there is usually an eosinophilic, Th2-dominated cell infiltration [1]. Due to the mucosa of the upper and lower airways being permeable to various antigens (e.g., allergic antigens, bacterial antigens, nanoparticles) because of barrier disruption, epithelial cells are able to activate dendritic cells (DC) in the environment by producing thymic stromal lymphopoietin (TSLP). Interaction between the 0X40 receptor (also known as CD134) on naïve $\mathrm{T}$ cells and the OX40 ligand on DCs induces CD4+ T cells to differentiate into Th2 cells $[9,10]$. The further inflammatory process is characterised by interleukin (IL)-4 and IL-5 production by these Th2 cells, as well as eosinophil cationic protein (ECP) and eotaxin-1/-2/-3 [11,12]. Each of these cytoand chemokines has specific functions. IL-4 is a mediator and modulator of the immune and inflammatory response and is mainly produced by Th2 cells. In addition, IL-4 is able to promote the differentiation of CD4+ T cells into Th2 cells, while inhibiting IFN $\gamma$ production and Th1 response $[13,14]$. Recently, it has been shown that there is an upregulation of IL-4 in nasal polyps, whereas IFN $\gamma$ is expressed in a decreased manner and does not differ significantly between nasal polyps and control tissues $[12,15,16]$. IL-5 is the major eosinophilactivating cytokine and promotes the tissue survival of mature eosinophils $[17,18]$. IL-5 is upregulated in nasal polyps [19] and plays an important role in their pathogenesis. ECP and eotaxin promote eosinophil attraction and activation, and are also upregulated in nasal polyps [11,12,20].

IL-6, as a proinflammatory cytokine, is capable of inhibiting neutrophil recruitment [21-23]. It has also been found to be upregulated in CRSwNP [24,25]. However, based on the different published data regarding regulatory molecules of the IL- 6 pathway, it remains unclear as to whether the IL-6 pathway is aa part of the pathogenesis of CRSwNP.

Keswani, et al. [26] and Cho, et al. [27] found increased expressions of IL-32 in total tissue extracts of nasal polyps. IL-32 is also described as a proinflammatory cytokine that induces cells of the immune system - such as monocytes and macrophages - to secrete inflammatory cytokines [2833]. In this regard, IL-32 appears to play a role in various inflammatory diseases such as chronic obstructive pulmonary disease (COPD) and atopic dermatitis [34,35]. There are now 9 different known isoforms of IL-32, although the functional differences remain unclear $[29,36]$. Further studies are needed to assess the role of IL-32 in the nasal polyps of patients with chronic rhinosinusitis.

IL-25 and IL-33 are other cytokines produced in sinonasal epithelial cells that support the Th2 inflammation of CRSwNP [37-39]. IL-25 is upregulated in nasal polyps and increases thymic stromal lymphopoietin (TSLP)-induced Th2 cell expansion [40,41]. TSLP has previously been shown to have increased expression in the epithelium of patients with CRSwNP [42-44]. This is an IL-7-like cytokine, and, in combination with IL-1, mast cells are effectively activated to produce Th2 cytokines, including IL-5 and IL-13 [45].

A study from Baltimore (US) could demonstrate that sinonasal epithelial cells from patients with untreated CRSwNP show an increased baseline expression of IL-33 compared to sinonasal epithelial cells from patients with CRSwNP after treatment with methylprednisolone [46]. This increased expression of IL-33 in untreated polyps was confirmed by another research group (47). IL-33 is a local alarmin for various immune cells. In addition, IL-33 is a chemoattractant for Th2 cells and promotes the production of Th2 cytokines such as IL-4, IL-5 and IL-13. Airway epithelial cells can produce IL-33, and its receptor is expressed by eosinophils and Th2 lymphocytes, among others [48]. IL-33 plays a significant role in the maintenance of Th2-mediated eosinophilic inflammation [49], and polymorphisms within the IL-33 receptor gene - the interleukin-1 receptor-like 1 (IL1RL1) gene - have been linked to the severity of CRS [50]. IL-25 and IL-33 are thought to link epithelial cells to the Th2 response [37]; however, this requires further investigation.

On the other hand, the cytokines IL-25, IL-33, and TSLP have effects on the so-called type 2 innate lymphoid cells (ILC2) [51]. ILCs are lymphocyte-like cells that do not express allergen-specific T-cell receptors. In this regard, ILC2 cells are considered to be the counterpart of Th2 cells, as both produce cytokines such as IL-5 and IL-13 [52]. Thus, ILC2s activated by IL-33 and IL-25 can induce eosinophilic airway inflammation $[53,54]$. ILC2s are abundant in nasal polyps and are associated with (i) increased numbers of eosinophils in the blood and tissues of patients with CRSwNP, (ii) clinically relevant worsening of TNSS (Total Nasal Symptom Score) and (iii) asthma comorbidity $[55,56]$.

In addition to eotaxin-1/-2/-3, several chemokines such as CCL5 (RANTES), CXCL8 (IL-8), CCL23, CCL18, CXCL12 (SDF$1 \alpha$ ), and CXCL13 (BCA-1) have been linked to the selective recruitment of inflammatory cells to mucosal tissue in CRSwNP. RANTES was one of the first identified chemokines to be found upregulated in nasal polyps $[57,58]$. RANTES is a member of the CC chemokine family and is a potent chemoattractant 
for eosinophils and T lymphocytes, but not for neutrophils. It is primarily secreted by nasal epithelial cells $[57,59,60]$. Expression as well as secretion of RANTES also occurs in nasal polyps. Interestingly, nasal polyps with high numbers of eosinophils have a significantly increased RANTES gene and protein expression. Consequently, increased RANTES expression leads to increased numbers of eosinophils in the tissue. Thus, RANTES is also likely to play an important role in the mobilisation of eosinophils in nasal polyps.

Another role in the inflammation of nasal polyps is played by CXCL8 (IL-8), which attracts neutrophils and eosinophils to the nasal mucosa, provided they have been previously activated by IL-5 [61]. However, IL-8 is considered as rather a nonspecific marker for CRSwNP. While altered levels of IL-8 have been identified in nasal polyps [25,61-64], upregulation remains without clear correlation to nasal polyp formation [61].

Poposki, et al. [65] demonstrated a strong production of CCL23 in nasal polyps, which was largely colocalised with ECP, suggesting a predominant eosinophilic CCL23 production in nasal polyps. CCL23 is a chemoattractant for monocytes, dendritic cells and lymphocytes. It has been shown to induce endothelial cell migration via the chemokine receptor CCR1, which is also upregulated in nasal polyps [65-68]. Th2 cytokines such as IL-4 and IL-13 have been shown to induce CCL23 expression in monocytes [69].

Significantly increased CCL18 mRNA expression was also found in nasal polyps and inferior turbinates [70]. In CRSwNP, M2 macrophages and mast cells were identified to express CCL18, which can be induced by the Th2 cytokines IL4-, IL-13, and IL-10 [70]. Because the associated receptor CCR8 has only recently been identified, the role of CCL18 in the pathogenesis of CRSwNP has not yet been studied in detail [71]. However, this discovery will help clarify the role of CLL18 in CRSwNP.

B cells as well as IgA and IgE antibody fractions have been found to be elevated in patients with CRSwNP [72,73]. B cells express IgA, which triggers the degranulation of eosinophils and represents a possible link to CRSwNP [72]. In this context, the chemokines CXCL12 (SDF-1 $\alpha$ ) and CXCL13 (BCA-1) have been shown to be increased in nasal polyps. Both of them attract B cells. Furthermore, the receptors for SDF-1 $\alpha$ (CXCR4 and CXCR7) and BCA-1 (CXCR5) are also present at elevated levels [74]. Accordingly, in nasal polyps, the expression of SDF- $1 \alpha$ and BCA- 1 may be important for the recruitment and maintenance of B cells. In addition, the elevated IgA levels imply an important role of $B$ cells in the pathogenesis of CRSwNP.

\section{Clinical trials with biologicals in CRSwNP}

Biologicals include therapeutics produced by biotechnological methods, particularly by the gene transfection of cells or other organisms. The most prominent group of biologicals are monoclonal antibodies, which, in recent decades, have been increasingly used in socalled immunotherapy. Treatment of atopy, asthma, and other eosinophilic disorders with monoclonal therapeutic antibodies has increased dramatically in recent years [75-78]. For severe and refractory asthmatic syndromes, an antibody has already been approved for therapy, one that binds free $\mathrm{IgE}$ and reduces IgE receptor density on immune cells [79]. It is now undisputed that a large number of patients with CRSwNP also have comorbid bronchial asthma, and vice versa [80-82]. In particular, high levels of total IgE, ECP, and IgE against S. aureus are associated with lower and upper respiratory tract comorbidity and a high rate of polyposis recurrence after sinonasal surgery $[81,83]$. Based on this comorbidity, current and past studies have applied antibodies known in asthma therapy to CRSwNP, and have achieved significant success in some cases.

\section{Further targets for therapy with biologicals}

By studying nasal polyp tissue for the expression of inflammatory mediators and cellular markers, new potential targets for targeted therapy with biologicals in CRSwNP are continuously being identified. The same is true regarding experience in asthma therapy, of which the applicability to chronic sinusitis is being reviewed. Kimura, et al., Liu, et al. and other groups demonstrated increased concentrations of thymic stromal lymphopoietin (TSLP) in the polyp tissue of patients with CRSwNP [42-44]. Among these, the concentration was highest in allergic rhinitis with polyposis. Tissue dendritic cells (DC), which were also examined, showed an increased expression of the TSLP receptor and OX40 ligand (OX40L) compared with tissue from healthy subjects [43]. Anti-TSLP and anti-OX40L antibodies have already been studied in the context of asthma in clinical trials. They were able to reduce eosinophils in sputum, while anti-TSLP antibodies were also able to reduce eosinophils in blood $[75,126]$. The results of further studies with anti-TSLP antibodies are currently pending $[127,128]$. At the present time, there are no known clinical trials investigating TSLP or OX40L blockade in CRSwNP.

In 2013 and 2014, a phase I trial of a monoclonal therapeutic antibody against IL1RL1 was initiated in patients with CRSwNP and asthma, respectively $[129,130]$. AMG282 prevents the binding of IL-33 (whose key role has been described above) to its receptor IL1RL1. Results of these safety, tolerability, and pharmacokinetics studies are currently pending, and other IL1RL antibodies from other pharmaceutical companies, such as CNTO7160, are in preclinical and clinical development. A phase II trial investigating AK001 - currently reported as being a SIGLEC8 ligand or antibody - in the treatment of CRSwNP is not presently in the recruitment phase [131,132]. SIGLEC8 is expressed on eosinophils, mast cells, and basophils, and binding of a SIGLEC8 ligand induces apoptosis in eosinophils [133]. This proapoptotic effect appears to be further 
modulated by the presence of IL-33 and IL-5 [134,135]. The primary endpoints of the study were reduction in polyp size and CT polyp score (Lund-Mackay).

Studies investigating the effect of blockade of IL-2, tumour necrosis-factor-alpha (TNF $\alpha$ ), and other cytokines and chemokines have been conducted only for asthma or atopic eczema indications, but not for CRSwNP. TNF $\alpha$ blockade, which has been well studied in rheumatoid disease and inflammatory bowel disease, has led to equivocal results and tolerability issues in asthma $[136,137]$. A phase II study of the treatment of asthma with daclizumab, an IL-2 receptor alpha antibody already approved to prevent rejection after kidney transplantation, showed promising results in terms of reduction of blood eosinophilia, ECP levels, asthma symptoms, and use of beta-mimetics as on-demand medication [138]. To date, this is the only study on daclizumab in asthma. Studies for the indication of CRSwNP have not yet been announced.

\section{Conclusion}

CRS is a heterogeneous group of inflammatory diseases of the mucous membranes of the nose and paranasal sinuses. In clinical routine, the disease is currently still divided into CRSsNP and CRSwNP based on phenological features.

However, especially for CRSwNP, different pathomechanisms exist that lead to the expression of the polyps. These different endotypes exhibit differential signalling pathways from the process of inflammation initiation, maintenance, and chronification to tissue alteration. In addition to the "classic" CRSwNP endotype of Th2-based and eosinophil-dominated inflammation, other endotypes exist that suggest different therapeutic approaches [139]. Examples include the use of biologics such as dupilumab (anti-IL-4/13), mepolizumab (anti-IL-5), or omalizumab (anti-IgE) [140,141].

These endotype-based treatment approaches target a specific pathophysiological pathway and are thus based on a careful selection of the patient population. Under these conditions, positive treatment success in CRSwNP has been demonstrated for the above-mentioned monoclonal antibodies against IgE, IL-5, and IL-4/13 [139].

However, the addition of individualised treatment options to "basic therapy options" could help to realise the principle of "personalised medicine", also for CRS in the future. Easily determinable biomarkers $([13,30]$ and clinical documentation parameters [142] are needed to establish these options in clinical routine, and their development is currently being pursued.

\section{References}

1. Fokkens WJ, Lund VJ, Mullol J, Bachert C, Alobid I, et al. European Position Paper on Rhinosinusitis and Nasal Polyps 2012. Rhinology Supplement. Rhinology. 2012; 50: 1-12.

PubMed: https://pubmed.ncbi.nlm.nih.gov/22469599/

2. Hastan D, Fokkens WJ, Bachert C, Newson RB, Bislimovska J, et al. Chronic rhinosinusitis in Europe--an underestimated disease. A GA(2)
LEN study. Allergy. 2011; 66: 1216-1223.

PubMed: https://pubmed.ncbi.nlm.nih.gov/21605125/

3. Stuck BA, Beule A, Jobst D, Klimek L, Laudien M, et al. [Guideline for "rhinosinusitis"-long version : S2k guideline of the German College of General Practitioners and Family Physicians and the German Society for Oto-Rhino-Laryngology, Head and Neck Surgery]. HNO. 2018;66:38-74. PubMed: https://pubmed.ncbi.nlm.nih.gov/28861645/

4. Rosenfeld RM, David A, Neil B, Dickson C, Steven E, et al. Clinical practice guideline on adult sinusitis. Otolaryngol Head Neck Surg. 2007; 137: 365-377

PubMed: https://pubmed.ncbi.nlm.nih.gov/17761281/

5. Koennecke M, Klimek L, Mullol J, Gevaert P, Wollenberg B. Subtyping of polyposis nasi: phenotypes, endotypes and comorbidities. Allergo $\mathrm{J}$ Int. 2018; 27: 56-65

PubMed: https://pubmed.ncbi.nlm.nih.gov/29564208/

6. Calus L, Van Zele T, Derycke L, Krysko O, Dutre T, et al. Local inflammation in chronic upper airway disease. Curr Pharm Des. 2012; 18: 2336-2346.

PubMed: https://pubmed.ncbi.nlm.nih.gov/22390697/

7. Annunziato $\mathrm{F}$, Romagnani $\mathrm{S}$. Heterogeneity of human effector $\mathrm{CD} 4+\mathrm{T}$ cells. Arthritis Res Ther. 2009; 11: 257.

PubMed: https://pubmed.ncbi.nlm.nih.gov/20053303/

8. Zygmunt B, Veldhoen M. T helper cell differentiation more than just cytokines. Adv Immunol. 2011; 109: 159-196.

PubMed: https://pubmed.ncbi.nlm.nih.gov/21569915/

9. Kaur D, Brightling C. OX40/OX40 ligand interactions in T-cell regulation and asthma. Chest. 2012; 141: 494-499.

PubMed: https://pubmed.ncbi.nlm.nih.gov/22315115/

10. Lane P. Role of OX40 signals in coordinating CD4 T cell selection, migration, and cytokine differentiation in T helper (Th)1 and Th2 cells. J Exp Med. 2000; 191: 201-206.

PubMed: https://pubmed.ncbi.nlm.nih.gov/10637265/

11. Plager DA, Kahl JC, Asmann YW, Nilson AE, Pallanch JF, et al. Gene transcription changes in asthmatic chronic rhinosinusitis with nasal polyps and comparison to those in atopic dermatitis. PLoS One. 2010; 5: e11450.

PubMed: https://pubmed.ncbi.nlm.nih.gov/20625511/

12. Van Zele T, Claeys S, Gevaert P, Van Maele G, Holtappels G, et al. Differentiation of chronic sinus diseases by measurement of inflammatory mediators. Allergy. 2006; 61: 1280-1289.

PubMed: https://pubmed.ncbi.nlm.nih.gov/17002703/

13. Kopf M, Le Gros G, Bachmann M, Lamers MC, Bluethmann H, et al. Disruption of the murine IL-4 gene blocks Th2 cytokine responses. Nature. 1993; 362: 245-248.

PubMed: https://pubmed.ncbi.nlm.nih.gov/8384701/

14. Ouyang W, Ranganath SH, Weindel K, Bhattacharya D, Murphy TL, et al. Inhibition of Th1 development mediated by GATA-3 through an IL-4-independent mechanism. Immunity. 1998; 9: 745-755. PubMed: https://pubmed.ncbi.nlm.nih.gov/9846495/

15. Derycke L, Eyerich S, Van Crombruggen K, Perez-Novo C, Holtappels G, et al. Mixed Thelper cell signatures in chronic rhinosinusitis with and without polyps. PloS One. 2014; 9: e97581. https://pubmed.ncbi.nlm.nih.gov/24911279/

16. Danielsen A, Tynning T, Brokstad KA, Olofsson J, Davidsson A Interleukin 5, IL6, IL12, IFN-gamma, RANTES and Fractalkine in human nasal polyps, turbinate mucosa and serum. Eur Arch Otorhinolaryngol. 2006; 263: 282-289.

PubMed: https://pubmed.ncbi.nlm.nih.gov/16456693/

17. Li Z, Zhang Y, Sun B. Current understanding of Th2 cell differentiation and function. Protein Cell. 2011; 2: 604-611.

PubMed: https://pubmed.ncbi.nlm.nih.gov/21904976/

18. Prussin $C$, Yin $Y$, Upadhyaya B. $T(H) 2$ heterogeneity: Does function follow form? J Allergy Clin Immunol. 2010; 126: 1094-1098. PubMed: https://pubmed.ncbi.nlm.nih.gov/20951419/ 
19. Bachert C, Wagenmann M, Hauser U, Rudack C. IL-5 synthesis is upregulated in human nasal polyp tissue. J Allergy Clin Immunol. 1997; 99: 837-842.

PubMed: https://pubmed.ncbi.nlm.nih.gov/9215253/

20. Bachert C, Gevaert P, Holtappels G, Cuvelier C, van Cauwenberge P. Nasalpolyposis: from cytokinestogrowth. Am JRhinol.2000;14:279-290. PubMed: https://pubmed.ncbi.nlm.nih.gov/11068652/

21. Hurst SM, Wilkinson TS, McLoughlin RM, Jones $S$, Horiuchi $S$, et al II-6 and its soluble receptor orchestrate a temporal switch in the pattern of leukocyte recruitment seen during acute inflammation. Immunity. 2001; 14: 705-714.

PubMed: https://pubmed.ncbi.nlm.nih.gov/11420041/

22. Jones SA. Directing transition from innate to acquired immunity: defining a role for IL-6. J Immunol. 2005; 175: 3463-3468.

PubMed: https://pubmed.ncbi.nlm.nih.gov/16148087/

23. Kaplanski G, Marin V, Montero-Julian F, Mantovani A, Farnarier C. IL6: a regulator of the transition from neutrophil to monocyte recruitment during inflammation. Trends Immunol. 2003; 24: 25-29.

PubMed: https://pubmed.ncbi.nlm.nih.gov/12495721/

24. Peters AT, Kato A, Zhang N, Conley DB, Suh L, et al. Evidence for altered activity of the IL-6 pathway in chronic rhinosinusitis with nasal polyps. J Allergy Clin Immunol. 2010; 125: 397-403 e10. PubMed: https://pubmed.ncbi.nlm.nih.gov/20159251/

25. Tomassen P, Vandeplas G, Van Zele T, Cardell LO, Arebro J, et al. Inflammatory endotypes of chronic rhinosinusitis based on cluster analysis of biomarkers. J Allergy Clin Immunol. 2016; 137: 1449-1456. PubMed: https://pubmed.ncbi.nlm.nih.gov/26949058/

26. Keswani A, Chustz RT, Suh L, Carter R, Peters AT, et al. Differential expression of interleukin-32 in chronic rhinosinusitis with and without nasal polyps. Allergy. 2012; 67: 25-32.

PubMed: https://pubmed.ncbi.nlm.nih.gov/21899560/

27. Cho JS, Kim JA, Park JH, Park IH, Han IH, et al. Toll-like receptor 4-mediated expression of interleukin-32 via the c-Jun N-terminal kinase/protein kinase $\mathrm{B} / \mathrm{cyclic}$ adenosine monophosphate response element binding protein pathway in chronic rhinosinusitis with nasal polyps. Int Forum Allergy Rhinol. 2016; 6: 1020-1028. PubMed: https://pubmed.ncbi.nlm.nih.gov/27173130/

28. Bai X, Kim SH, Azam T, McGibney MT, Huang H, et al. IL-32 is a host protective cytokine against Mycobacterium tuberculosis in differentiated THP-1 human macrophages. J Immunol. 2010; 184: 3830-3840. PubMed: https://pubmed.ncbi.nlm.nih.gov/20190143/

29. Dinarello CA, Kim SH. IL-32, a novel cytokine with a possible role in disease. Ann Rheum Dis. 2006; 65 Suppl 3: iii61-64.

PubMed: https://pubmed.ncbi.nlm.nih.gov/17038476/

30. Kim SH, Han SY, Azam T, Yoon DY, Dinarello CA. Interleukin-32: a cytokine and inducer of TNFalpha. Immunity. 2005; 22: 131-142. PubMed: https://pubmed.ncbi.nlm.nih.gov/15664165/

31. Li W, Sun W, Liu L, Yang F, Li Y, et al. IL-32: a host proinflammatory factor against influenza viral replication is upregulated by aberrant epigenetic modifications during influenza A virus infection. J Immunol. 2010; 185: 5056-5065.

PubMed: https://pubmed.ncbi.nlm.nih.gov/20889550/

32. Netea MG, Azam T, Lewis EC, Joosten LA, Wang M, etal. Mycobacterium tuberculosis induces interleukin-32 production through a caspase- $1 / \mathrm{IL}$ 18/interferon-gamma-dependent mechanism. PLoS Med. 2006; 3: e277. PubMed: https://pubmed.ncbi.nlm.nih.gov/16903774/

33. Nold MF, Nold-Petry CA, Pott GB, Zepp JA, Saavedra MT, et al. Endogenous IL-32 controls cytokine and HIV-1 production. J Immunol. 2008; 181: 557-565.

PubMed: https://pubmed.ncbi.nlm.nih.gov/18566422/

34. Calabrese F, Baraldo S, Bazzan E, Lunardi F, Rea F, et al. IL-32, a novel proinflammatory cytokine in chronic obstructive pulmonary disease. Am J Respir Crit Care Med. 2008; 178: 894-901.

PubMed: https://pubmed.ncbi.nlm.nih.gov/18703789/
35. Meyer N, Zimmermann M, Burgler S, Bassin C, Woehrl S, et al. IL-32 is expressed by human primary keratinocytes and modulates keratinocyte apoptosis in atopic dermatitis. JAllergy Clin Immunol. 2010; 125:858-865. PubMed: https://pubmed.ncbi.nlm.nih.gov/20227751/

36. Kang JW, Park YS, Lee DH, Kim MS, Bak Y, et al. Interaction network mapping among IL-32 isoforms. Biochimie. 2014; 101: 248-251. PubMed: https://pubmed.ncbi.nlm.nih.gov/24472437/

37. Chin D, Harvey RJ. Nasal polyposis: an inflammatory condition requiring effective anti-inflammatory treatment. Curr Opin Otolaryngol Head Neck Surg. 2013; 21: 23-30.

PubMed: https://pubmed.ncbi.nlm.nih.gov/23172039/

38. Lam EP, Kariyawasam HH, Rana BM, Durham SR, McKenzie AN, et al IL-25/IL-33-responsive TH2 cells characterize nasal polyps with a default TH17 signature in nasal mucosa. J Allergy Clin Immunol. 2016; 137: 1514-1524.

PubMed: https://pubmed.ncbi.nlm.nih.gov/26684290/

39. Kato A. Immunopathology of chronic rhinosinusitis. Allergol Int. 2015; 64: $121-130$

PubMed: https://pubmed.ncbi.nlm.nih.gov/25838086/

40. Wang YH, Angkasekwinai P, Lu N, Voo KS, Arima K, et al. IL-25 augments type 2 immune responses by enhancing the expansion and functions of TSLP-DC-activated Th2 memory cells. J Exp Med. 2007; 204: $1837-1847$

PubMed: https://pubmed.ncbi.nlm.nih.gov/17635955/

41. Shin HW, Kim DK, Park MH, Eun KM, Lee M, et al. IL-25 as a nove therapeutic target in nasal polyps of patients with chronic rhinosinusitis. J Allergy Clin Immunol. 2015; 135: 1476-1485.

PubMed: https://pubmed.ncbi.nlm.nih.gov/25725991/

42. Kimura S, Pawankar R, Mori S, Nonaka M, Masuno S, et al. Increased expression and role of thymic stromal lymphopoietin in nasal polyposis. Allergy Asthma Immunol Res. 2011; 3: 186-193. PubMed: https://pubmed.ncbi.nlm.nih.gov/21738884/

43. Liu T, Li TL, Zhao F, Xie C, Liu AM, et al. Role of thymic stromal lymphopoietin in the pathogenesis of nasal polyposis. Am J Med Sci. 2011; 341: 40-47.

PubMed: https://pubmed.ncbi.nlm.nih.gov/20924287/

44. Nagarkar DR, Poposki JA, Tan BK, Comeau MR, Peters AT, et al. Thymic stromal lymphopoietin activity is increased in nasal polyps of patients with chronic rhinosinusitis. J Allergy Clin Immunol. 2013; 132: 593-600. PubMed: https://pubmed.ncbi.nlm.nih.gov/23688414/

45. Nagarkar DR, Poposki JA, Comeau MR, Biyasheva A, Avila PC, et al. Airway epithelial cells activate TH2 cytokine production in mast cells through IL-1 and thymic stromal lymphopoietin. J Allergy Clin Immunol. 2012; 130: 225-232.

PubMed: https://pubmed.ncbi.nlm.nih.gov/22633328/

46. Reh DD, Wang Y, Ramanathan M, Lane AP. Treatment-recalcitrant chronic rhinosinusitis with polyps is associated with altered epithelial cell expression of interleukin-33. Am J Rhinol Allergy. 2010; 24: 105-109. PubMed: https://pubmed.ncbi.nlm.nih.gov/20338108/

47. Kim DK, Jin HR, Eun KM, Mo JH, Cho $\mathrm{SH}$, et al. The role of interleukin-33 in chronic rhinosinusitis. Thorax. 2017; 72: 591-593. PubMed: https://pubmed.ncbi.nlm.nih.gov/28242750/

48. Arend WP, Palmer G, Gabay C. IL-1, IL-18, and IL-33 families of cytokines. Immunol Rev. 2008; 223: 20-38.

PubMed: https://pubmed.ncbi.nlm.nih.gov/18613828/

49. Cherry WB, Yoon J, Bartemes KR, lijima K, Kita H. A novel IL-1 family cytokine, IL-33, potently activates human eosinophils. J Allergy Clin Immunol. 2008; 121: 1484-1490.

PubMed: https://pubmed.ncbi.nlm.nih.gov/18539196/

50. Castano R, Bosse Y, Endam LM, Desrosiers M. Evidence of association of interleukin-1 receptor-like 1 gene polymorphisms with chronic rhinosinusitis. Am J Rhinol Allergy. 2009; 23: 377-384. PubMed: https://pubmed.ncbi.nlm.nih.gov/19671251/

51. Mjosberg JM, Trifari S, Crellin NK, Peters CP, van Drunen CM, et al. Human IL-25- and IL-33-responsive type 2 innate lymphoid cells are defined by 
expression of CRTH2 and CD161. Nat Immunol. 2011; 12: 1055-1062. PubMed: https://pubmed.ncbi.nlm.nih.gov/21909091/

52. Robinette ML, Colonna M. Immune modules shared by innate lymphoid cells and T cells. J Allergy Clin Immunol. 2016; 138: 1243-1251. PubMed: https://pubmed.ncbi.nlm.nih.gov/27817796/

53. Kim HY, Chang YJ, Subramanian S, Lee HH, Albacker LA, et al. Innate lymphoid cells responding to IL-33 mediate airway hyperreactivity independently of adaptive immunity. J Allergy Clin Immunol. 2012 129: $216-227$.

PubMed: https://pubmed.ncbi.nlm.nih.gov/22119406/

54. Morita H, Moro K, Koyasu S. Innate lymphoid cells in allergic and nonallergic inflammation. J Allergy Clin Immunol. 2016; 138: 1253-1264. PubMed: https://pubmed.ncbi.nlm.nih.gov/27817797/

55. Ho J, Bailey M, Zaunders J, Mrad N, Sacks R, et al. Cellular comparison of sinus mucosa vs polyp tissue from a single sinus cavity in chronic rhinosinusitis. Int Forum Allergy Rhinol. 2015; 5: 14-27. PubMed: https://pubmed.ncbi.nlm.nih.gov/25332132/

56. Ho J, Bailey M, Zaunders J, Mrad N, Sacks R, et al. Group 2 innate lymphoid cells (ILC2s) are increased in chronic rhinosinusitis with nasal polyps or eosinophilia. Clin Exp Allergy. 2015; 45: 394-403.

PubMed: https://pubmed.ncbi.nlm.nih.gov/25429730/

57. Beck LA, Stellato C, Beall LD, Schall TJ, Leopold D, et al. Detection of the chemokine RANTES and endothelial adhesion molecules in nasa polyps. J Allergy Clin Immunol. 1996; 98: 766-780.

PubMed: https://pubmed.ncbi.nlm.nih.gov/8876553/

58. Davidsson A, Danielsen A, Viale G, Olofsson J, Dell'Orto P, et al Positive identification in situ of mRNA expression of IL-6, and IL-12, and the chemotactic cytokine RANTES in patients with chronic sinusitis and polypoid disease. Clinical relevance and relation to allergy. Acta Otolaryngol. 1996; 116: 604-610.

PubMed: https://pubmed.ncbi.nlm.nih.gov/8831850/

59. Allen JS, Eisma R, LaFreniere D, Leonard G, Kreutzer D. Characterization of the eosinophil chemokine RANTES in nasal polyps. The Annals of otology, rhinology, and laryngology. 1998; 107: 416-420. PubMed: https://pubmed.ncbi.nlm.nih.gov/9596221/

60. Meyer JE, Bartels J, Gorogh T, Sticherling M, Rudack C, et al. The role of RANTES in nasal polyposis. Am J Rhinol. 2005; 19: 15-20. PubMed: https://pubmed.ncbi.nlm.nih.gov/15794069/

61. Chen YS, Arab SF, Westhofen M, Lorenzen J. Expression of interleukin-5, interleukin-8, and interleukin-10 mRNA in the osteomeatal complex in nasal polyposis. Am J Rhinol. 2005; 19: 117-123. PubMed: https://pubmed.ncbi.nlm.nih.gov/15921209/

62. Kostamo K, Sorsa T, Leino M, Tervahartiala T, Alenius $\mathrm{H}$, et al. In vivo relationship between collagenase-2 and interleukin-8 but not tumour necrosis factor-alpha in chronic rhinosinusitis with nasal polyposis. Allergy. 2005; 60: 1275-1279.

PubMed: https://pubmed.ncbi.nlm.nih.gov/16134994/

63. Scavuzzo MC, Fattori B, Ruffoli R, Rocchi V, Carpi A, et al. Inflammatory mediators and eosinophilia in atopic and non-atopic patients with nasal polyposis. Biomed Pharmacother. 2005; 59: 323-329. PubMed: https://pubmed.ncbi.nlm.nih.gov/15935609/

64. Wang X, Zhang N, Bo M, Holtappels G, Zheng M, et al. Diversity of TH cytokine profiles in patients with chronic rhinosinusitis: A multicenter study in Europe, Asia, and Oceania. J Allergy Clin Immunol. 2016; 138: 1344-1353.

PubMed: https://pubmed.ncbi.nlm.nih.gov/27544740/

65. Poposki JA, Uzzaman A, Nagarkar DR, Chustz RT, Peters AT, et al Increased expression of the chemokine CCL23 in eosinophilic chronic rhinosinusitis with nasal polyps. J Allergy Clin Immunol. 2011; 128: 73-81. PubMed: https://pubmed.ncbi.nlm.nih.gov/21497884/

66. Bachert C, Van Cauwenberge PB. Inflammatory mechanisms in chronic sinusitis. Acta Otorhinolaryngol Belg. 1997; 51: 209-217. PubMed: https://pubmed.ncbi.nlm.nih.gov/9444369/

67. Fundova P, Funda DP, Kovar D, Holy R, Navara M, Tlaskalova-
Hogenova $\mathrm{H}$. Increased expression of chemokine receptors CCR1 and CCR3 in nasal polyps: molecular basis for recruitment of the granulocyte infiltrate. Folia Microbiol (Praha). 2013; 58: 219-224. PubMed: https://pubmed.ncbi.nlm.nih.gov/23054685/

68. Patel VP, Kreider BL, Li Y, Li H, Leung K, et al. Molecular and functional characterization of two novel human $\mathrm{C}-\mathrm{C}$ chemokines as inhibitors of two distinct classes of myeloid progenitors. J Exp Med. 1997; 185: 1163-1172. PubMed: https://pubmed.ncbi.nlm.nih.gov/9104803/

69. Novak H, Muller A, Harrer N, Gunther C, Carballido JM, et al. CCL23 expression is induced by IL-4 in a STAT6-dependent fashion. J Immunol. 2007; 178: 4335-4341.

PubMed: https://pubmed.ncbi.nlm.nih.gov/17371990/

70. Peterson S, Poposki JA, Nagarkar DR, Chustz RT, Peters AT, et al Increased expression of CC chemokine ligand 18 in patients with chronic rhinosinusitis with nasal polyps. J Allergy Clin Immunol. 2012 129: 119-127.

PubMed: https://pubmed.ncbi.nlm.nih.gov/21943944/

71. Islam SA, Ling MF, Leung J, Shreffler WG, Luster AD. Identification of human CCR8 as a CCL18 receptor. J Exp Med. 2013; 210: 1889-1898. PubMed: https://pubmed.ncbi.nlm.nih.gov/23999500/

72. Kato A, Peters A, Suh L, Carter R, Harris KE, et al. Evidence of a role for $B$ cell-activating factor of the TNF family in the pathogenesis of chronic rhinosinusitis with nasal polyps. J Allergy Clin Immunol. 2008; 121: 1385-1392.

PubMed: https://pubmed.ncbi.nIm.nih.gov/18410958/

73. Polzehl D, Moeller P, Riechelmann H, Perner S. Distinct features of chronic rhinosinusitis with and without nasal polyps. Allergy. 2006; 61: 1275-1279.

PubMed: https://pubmed.ncbi.nlm.nih.gov/17002702/

74. Patadia M, Dixon J, Conley D, Chandra R, Peters A, et al. Evaluation of the presence of B-cell attractant chemokines in chronic rhinosinusitis. Am J Rhinol Allergy. 2010; 24: 11-16.

PubMed: https://pubmed.ncbi.nlm.nih.gov/20109310/

75. Gauvreau GM, O'Byrne PM, Boulet LP, Wang Y, Cockcroft D, et al. Effects of an anti-TSLP antibody on allergen-induced asthmatic responses. N Engl J Med. 2014; 370: 2102-2110.

PubMed: https://pubmed.ncbi.nlm.nih.gov/24846652/

76. Bel EH, Ortega HG, Pavord ID. Glucocorticoids and mepolizumab in eosinophilic asthma. N Engl J Med. 2014; 371: 2434-2444.

PubMed: https://pubmed.ncbi.nlm.nih.gov/25517713/

77. Wenzel S, Ford L, Pearlman D, Spector S, Sher L, et al. Dupilumab in persistent asthma with elevated eosinophil levels. N Engl J Med. 2013; 368: 2455-2466.

PubMed: https://pubmed.ncbi.nlm.nih.gov/23688323/

78. Pauwels B, Jonstam K, Bachert C. Emerging biologics for the treatment of chronic rhinosinusitis. Expert Rev Clin Immunol. 2015; 11: 349-361. PubMed: https://pubmed.ncbi.nlm.nih.gov/25651905/

79. Busse W, Corren J, Lanier BQ, McAlary M, Fowler-Taylor A, et al. Omalizumab, anti-IgE recombinant humanized monoclonal antibody, for the treatment of severe allergic asthma. J Allergy Clin Immunol. 2001; 108: 184-190.

PubMed: https://pubmed.ncbi.nlm.nih.gov/11496232/

80. Bachert C, Zhang L, Gevaert P. Current and future treatment options for adult chronic rhinosinusitis: Focus on nasal polyposis. J Allergy Clin Immunol. 2015; 136: 1431-1440.

PubMed: https://pubmed.ncbi.nlm.nih.gov/26654192/

81. Bachert C, Zhang N, Holtappels G, De Lobel L, van Cauwenberge $P$, et al. Presence of IL-5 protein and $\operatorname{lgE}$ antibodies to staphylococcal enterotoxins in nasal polyps is associated with comorbid asthma. J Allergy Clin Immunol. 2010; 126: 962-968.

PubMed: https://pubmed.ncbi.nlm.nih.gov/20810157/

82. Lehrer E, Mullol J, Agredo F, Alobid I. Management of chronic rhinosinusitis in asthma patients: is there still a debate? Curr Allergy Asthma Rep. 2014; 14: 440.

PubMed: https://pubmed.ncbi.nlm.nih.gov/24682772/ 
83. Van Zele T, Holtappels G, Gevaert P, Bachert C. Differences in initial immunoprofiles between recurrent and nonrecurrent chronic rhinosinusitis with nasal polyps. Am J Rhinol Allergy. 2014; 28: 192-198. PubMed: https://pubmed.ncbi.nlm.nih.gov/24980230/

84. Grundmann SA, Hemfort PB, Luger TA, Brehler R. Anti-lgE (omalizumab): a new therapeutic approach for chronic rhinosinusitis. J Allergy Clin Immunol. 2008; 121: 257-258.

PubMed: https://pubmed.ncbi.nlm.nih.gov/18206513/

85. Holgate ST, Djukanovic R, Casale T, Bousquet J. Anti-immunoglobulin $\mathrm{E}$ treatment with omalizumab in allergic diseases: an update on antiinflammatory activity and clinical efficacy. Clinical and experimental allergy: J British Soc Allergy Clin Immunol. 2005; 35: 408-416. PubMed: https://pubmed.ncbi.nlm.nih.gov/15836747/

86. Pinto JM, Mehta N, DiTineo M, Wang J, Baroody FM, et al. A randomized, double-blind, placebo-controlled trial of anti-lgE for chronic rhinosinusitis. Rhinology. 2010; 48: 318-324.

PubMed: https://pubmed.ncbi.nlm.nih.gov/21038023/

87. Vennera MDC, Sabadell C, Picado C, Spanish Omalizumab R Duration of the efficacy of omalizumab after treatment discontinuation in 'real life' severe asthma. Thorax. 2018. 73: 782-784.

PubMed: https://pubmed.ncbi.nlm.nih.gov/29079610/

88. Gevaert P, Calus L, Van Zele T, Blomme K, De Ruyck N, et al Omalizumab is effective in allergic and nonallergic patients with nasal polyps and asthma. J Allergy Clin Immunol. 2013; 131: 110-116. PubMed: https://pubmed.ncbi.nlm.nih.gov/23021878/

89. Felix-Redondo FJ, Fernandez-Berges D, Calderon A, ConsuegraSanchez L, Lozano L, et al. Prevalence of left-ventricular hypertrophy by multiple electrocardiographic criteria in general population: Hermex study. J Hypertens. 2012; 30: 1460-1467.

PubMed: https://pubmed.ncbi.nlm.nih.gov/22573128/

90. Calderon MA, Cox L, Casale TB, Moingeon P, Demoly P. Multipleallergen and single-allergen immunotherapy strategies in polysensitized patients: looking at the published evidence. J Allergy Clin Immunol. 2012; 129: 929-934.

PubMed: https://pubmed.ncbi.nIm.nih.gov/22244595/

91. Valenta R, Laffer S, Vrtala S, Gronlund H, Elfman L, et al. Recombinant allergens. Steps on the way to diagnosis and therapy of type I allergy. Adv Exp Med Biol. 1996; 409: 185-196.

PubMed: https://pubmed.ncbi.nlm.nih.gov/9095240/

92. Gauvreau GM, Arm JP, Boulet LP, Leigh R, Cockcroft DW, et al. Efficacy and safety of multiple doses of QGE031 (ligelizumab) versus omalizumab and placebo in inhibiting allergen-induced early asthmatic responses. J Allergy Clin Immunol. 2016; 138: 1051-1059.

PubMed: https://pubmed.ncbi.nlm.nih.gov/27185571/

93. Arm JP, Bottoli I, Skerjanec A, Floch D, Groenewegen A, et al Pharmacokinetics, pharmacodynamics and safety of QGE031 (ligelizumab), a novel high-affinity anti-lgE antibody, in atopic subjects. Clinical and experimental allergy. J British Soc Allergy Clin Immunol. 2014; 44: 1371-1385

PubMed: https://pubmed.ncbi.nlm.nih.gov/25200415/

94. Gauvreau GM, Harris JM, Boulet LP, Scheerens H, Fitzgerald JM, et al. Targeting membrane-expressed IgE B cell receptor with an antibody to the M1 prime epitope reduces IgE production. Sci Translational Med. 2014; 6: 243ra85.

PubMed: https://pubmed.ncbi.nlm.nih.gov/24990880/

95. Corrigan CJ, Kettner J, Doemer C, Cromwell O, Narkus A. Efficacy and safety of preseasonal-specific immunotherapy with an aluminiumadsorbed six-grass pollen allergoid. Allergy. 2005; 60: 801-807. PubMed: https://pubmed.ncbi.nlm.nih.gov/15876311/

96. Flood-Page P, Swenson C, Faiferman I, Matthews J, Williams M, et al A study to evaluate safety and efficacy of mepolizumab in patients with moderate persistent asthma. Am J Respira Crit Care Med. 2007; 176 1062-1071.

PubMed: https://pubmed.ncbi.nlm.nih.gov/17872493/

97. Flood-Page PT, Menzies-Gow AN, Kay AB, Robinson DS. Eosinophil's role remains uncertain as anti-interleukin- 5 only partially depletes numbers in asthmatic airway. Am J Respira Crit Care Med. 2003; 167: 199-204. PubMed: https://pubmed.ncbi.nlm.nih.gov/12406833/

98. Bel EH, Wenzel SE, Thompson PJ, Prazma CM, Keene ON, et al. Oral glucocorticoid-sparing effect of mepolizumab in eosinophilic asthma. New Engl J Med. 2014; 371: 1189-1197.

PubMed: https://pubmed.ncbi.nlm.nih.gov/25199060/

99. Gevaert $P$, Lang-Loidolt $D$, Lackner A, Stammberger $H$, Staudinger $H$, et al. Nasal IL-5 levels determine the response to anti-IL-5 treatment in patients with nasal polyps. J Allergy Clin Immunol. 2006; 118: 1133-1141. PubMed: https://pubmed.ncbi.nlm.nih.gov/17088140/

100. Gevaert P, Van Bruaene N, Cattaert T, Van Steen K, Van Zele T, et al Mepolizumab, a humanized anti-IL-5 mAb, as a treatment option for severe nasal polyposis. J Allergy Clin Immunol. 2011; 128: 989-995 PubMed: https://pubmed.ncbi.nlm.nih.gov/21958585/

101. Mepolizumab in Nasal Polyposis. https://clinicaltrials.gov/ct2/show/ NCT01362244

102. Effect of Mepolizumab in Severe Bilateral Nasal Polyps. https:// clinicaltrials.gov/ct2/show/NCT03085797

103. Castro M, Zangrilli J, Wechsler ME, Bateman ED, Brusselle GG, et al. Reslizumab for inadequately controlled asthma with elevated blood eosinophil counts: results from two multicentre, parallel, double-blind, randomised, placebo-controlled, phase 3 trials. Lancet Respir Med. 2015; 3: 355-366.

PubMed: https://pubmed.ncbi.nlm.nih.gov/25736990/

104. Castro M, Mathur S, Hargreave F, Boulet LP, Xie F, et al. Reslizumab for poorly controlled, eosinophilic asthma: a randomized, placebocontrolled study. Am J Respir Crit Care Med. 2011; 184: 1125-1132. PubMed: https://pubmed.ncbi.nlm.nih.gov/21852542/

105. Study of Chronic Rhinosinusitis Symptoms in Asthma Patients Undergoing Treatment With Reslizumab. https://clinicaltrials.gov/ct2/show/NCT03369574

106. Kolbeck R, Kozhich A, Koike M, Peng L, Andersson CK, et al. MEDI563, a humanized anti-IL-5 receptor alpha mAb with enhanced antibody-dependent cell-mediated cytotoxicity function. J Allergy Clin Immunol. 2010; 125: 1344-1345.

PubMed: https://pubmed.ncbi.nlm.nih.gov/20513525/

107. Berair R, Pavord ID. Rationale and clinical results of inhibiting interleukin-5 for the treatment of severe asthma. Curr Allergy Asthma Rep. 2013; 13: 469-476.

PubMed: https://pubmed.ncbi.nlm.nih.gov/23904099/

108. Laviolette M, Gossage DL, Gauvreau G, Leigh R, Olivenstein R, et al. Effects of benralizumab on airway eosinophils in asthmatic patients with sputum eosinophilia. J Allergy Clin Immunol. 2013; 132: 1086-1096. PubMed: https://pubmed.ncbi.nlm.nih.gov/23866823/

109. Mahdavinia M, Carter RG, Ocampo CJ, Stevens W, Kato A, et al. Basophils are elevated in nasal polyps of patients with chronic rhinosinusitis without aspirin sensitivity. J Allergy Clin Immunol. 2014; 133: 1759-1763.

PubMed: https://pubmed.ncbi.nlm.nih.gov/24636088/

110. Efficacy and Safety Study of Benralizumab for Patients With Severe Nasal Polyposis (OSTRO)

https://clinicaltrials.gov/ct2/show/NCT03401229

111. Corren J, Lemanske RF, Hanania NA, Korenblat PE, Parsey MV, et al Lebrikizumab treatment in adults with asthma. New Engl J Med. 2011; 365: 1088-1098.

112. De Boever EH, Ashman C, Cahn AP, Locantore NW, Overend P, et al. Efficacy and safety of an anti-IL-13 mAb in patients with severe asthma: a randomized trial. J Allergy Clin Immunol. 2014; 133: 989-996. PubMed: https://pubmed.ncbi.nlm.nih.gov/24582316/

113. Noonan M, Korenblat $P$, Mosesova S, Scheerens H, Arron JR, et al. Dose-ranging study of lebrikizumab in asthmatic patients not receiving inhaled steroids. J Allergy Clin Immunol. 2013; 132: 567-574. PubMed: https://pubmed.ncbi.nlm.nih.gov/23726041/ 
114. Oh CK, Geba GP, Molfino N. Investigational therapeutics targeting the IL-4/IL-13/STAT- 6 pathway for the treatment of asthma. European respiratory review. J Eur Respir Soc. 2010; 19: 46-54. PubMed: https://pubmed.ncbi.nlm.nih.gov/20956165/

115. Scheerens H, Arron JR, Zheng Y, Putnam WS, Erickson RW, et al The effects of lebrikizumab in patients with mild asthma following whole lung allergen challenge. Clinical and experimental allergy. J British Soc Allergy Clin Immunol. 2014; 44: 38-46. PubMed: https://pubmed.ncbi.nlm.nih.gov/24131304/

116. Novembre E, Galli E, Landi F, Caffarelli C, Pifferi M, et al. Coseasonal sublingual immunotherapy reduces the development of asthma in children with allergic rhinoconjunctivitis. J Allergy Clin Immunol. 2004; 114: 851-857.

PubMed: https://pubmed.ncbi.nlm.nih.gov/15480326/

117. Choy DF, Hart KM, Borthwick LA, Shikotra A, Nagarkar DR, et al. TH2 and TH17 inflammatory pathways are reciprocally regulated in asthma. Sci Translational Med. 2015; 7: 301ra129.

PubMed: https://pubmed.ncbi.nIm.nih.gov/26290411/

118. Corren J, Busse W, Meltzer EO, Mansfield L, Bensch G, et al. A randomized, controlled, phase 2 study of AMG 317, an IL-4Ralpha antagonist, in patients with asthma. Am J Respirat Criti Care Med. 2010; 181: 788-796.

PubMed: https://pubmed.ncbi.nlm.nih.gov/20056900/

119. Wenzel S, Wilbraham D, Fuller R, Getz EB, Longphre M. Effect of an interleukin-4 variant on late phase asthmatic response to allergen challenge in asthmatic patients: results of two phase 2a studies. Lancet. 2007; 370: 1422-1431.

PubMed: https://pubmed.ncbi.nlm.nih.gov/17950857/

120. Wenzel S, Castro M, Corren J, Maspero J, Wang L, et al. Dupilumab efficacy and safety in adults with uncontrolled persistent asthma despite use of medium-to-high-dose inhaled corticosteroids plus a longacting beta2 agonist: a randomised double-blind placebo-controlled pivotal phase $2 \mathrm{~b}$ dose-ranging trial. Lancet. 2016; 388: 31-44. PubMed: https://pubmed.ncbi.nlm.nih.gov/27130691/

121. Wenzel SE, Wang L, Pirozzi G. Dupilumab in persistent asthma. New Engl J Med. 2013; 369: 1276.

PubMed: https://pubmed.ncbi.nlm.nih.gov/24066755/

122. Wechsler ME. Inhibiting interleukin-4 and interleukin-13 in difficult-tocontrol asthma. New Engl J Med. 2013; 368: 2511-2513. PubMed: https://pubmed.ncbi.nlm.nih.gov/23688322/

123. Bachert C, Mannent L, Naclerio RM, Mullol J, Ferguson BJ, et al. Effect of Subcutaneous Dupilumab on Nasal Polyp Burden in Patients With Chronic Sinusitis and Nasal Polyposis: A Randomized Clinical Trial. JAMA. 2016; 315: 469-479.

PubMed: https://pubmed.ncbi.nlm.nih.gov/26836729/

124. Barajas-Espinosa A, Ochoa-Cortes F, Moos MP, Ramirez FD, Vanner SJ, et al. Characterization of the cysteinyl leukotriene 2 receptor in novel expression sites of the gastrointestinal tract. Am J Pathol. 2011; 178 : 2682-2689.

PubMed: https://pubmed.ncbi.nlm.nih.gov/21641390/

125. Stock C, Moosbauer D, Zugmann S, Simbeck T, Amereller M, et al. A novel method for in situ measurement of solubility via impedance scanning quartz crystal microbalance studies. Chem Commun (Camb). 2011; 47: 6984-6986.

PubMed: https://pubmed.ncbi.nlm.nih.gov/21594264/

126. Gauvreau GM, Boulet LP, Cockcroft DW, FitzGerald JM, Mayers I, et al. OX40L blockade and allergen-induced airway responses in subjects with mild asthma. Clinical and experimental allergy. J British Soc Allergy Clin Immunol. 2014; 44: 29-37.

PubMed: https://pubmed.ncbi.nlm.nih.gov/24224471/

127. Pfaar O, Mosges R, Hormann K, Klimek L. [Cluster immunotherapy of persistentallergicrhinoconjunctivitis. Safetyaspects of inductiontherapy with mite depot allergen preparations]. Hno. 2009; 57: 1099-1105. PubMed: https://pubmed.ncbi.nlm.nih.gov/19585090/
128. Klimek L, Pfaar O, Grevers G. Therapeutical options in allergic rhinitis. MMW Fortschr Med. 2009; 151: 31-34.

129. Pfaar O, Anders C, Klimek L. Clinical outcome measures of specific immunotherapy. Curr Opin Allergy Clin Immunol. 2009; 9: 208-213. PubMed: https://pubmed.ncbi.nlm.nih.gov/19365259/

130. Pfaar O, Klimek L, Fischer I, Sieber J, Amoroso S, et al. Safety of two cluster schedules for subcutaneous immunotherapy in allergic rhinitis or asthma patients sensitized to inhalant allergens. Int Arch Allergy Immunol. 2009; 150: 102-108.

PubMed: https://pubmed.ncbi.nlm.nih.gov/19339808/

131. Pfaar O, Raap U, Holz M, Hormann K, Klimek L. Pathophysiology of itchingand sneezing inallergicrhinitis. Swiss MedWkly. 2009;139:35-40. PubMed: https://pubmed.ncbi.nlm.nih.gov/19169901/

132. Kiwamoto T, Kawasaki N, Paulson JC, Bochner BS. Siglec-8 as a drugable target to treat eosinophil and mast cell-associated conditions. Pharmacol Therapeut. 2012; 135: 327-336.

PubMed: https://www.ncbi.nlm.nih.gov/pmc/articles/PMC3587973/

133. Nutku E, Aizawa H, Hudson SA, Bochner BS. Ligation of Siglec-8: a selective mechanism for induction of human eosinophil apoptosis. Blood. 2003; 101: 5014-5020

PubMed: https://pubmed.ncbi.nlm.nih.gov/12609831/

134. Na HJ, Hudson SA, Bochner BS. IL-33 enhances Siglec-8 mediated apoptosis of human eosinophils. Cytokine. 2012; 57: 169-174. PubMed: https://pubmed.ncbi.nlm.nih.gov/22079334/

135. Nutku E, Hudson SA, Bochner BS. Mechanism of Siglec-8-induced human eosinophil apoptosis: role of caspases and mitochondrial injury. Biochem Biophysi Res Commun. 2005; 336: 918-924. PubMed: https://pubmed.ncbi.nlm.nih.gov/16157303/

136. Wenzel SE, Barnes PJ, Bleecker ER, Bousquet J, Busse W, et al. A randomized, double-blind, placebo-controlled study of tumor necrosis factor-alpha blockade in severe persistent asthma. Am J Respir Criti Care Med. 2009; 179: 549-558.

PubMed: https://pubmed.ncbi.nlm.nih.gov/19136369/

137. Brightling C, BerryM,AmraniY. Targeting TNF-alpha:anoveltherapeutic approach for asthma. J Allergy Clin Immunol. 2008; 121: 5-10. PubMed: https://pubmed.ncbi.nlm.nih.gov/18036647/

138. Busse WW, Israel E, Nelson HS, Baker JW, Charous BL, et al. Daclizumab improves asthma control in patients with moderate to severe persistent asthma: a randomized, controlled trial. Am J Respir Crit Care Med. 2008; 178: 1002-1008

PubMed: https://pubmed.ncbi.nlm.nih.gov/18787222/

139. De Greve G, Hellings PW, Fokkens WJ, Pugin B, Steelant B, et al. Endotype-driven treatment in chronic upper airway diseases. Clin Transl Allergy. 2017; 7: 22

PubMed: https://pubmed.ncbi.nlm.nih.gov/28706720/

140. Bachert C, Gevaert P, Hellings P. Biotherapeutics in Chronic Rhinosinusitis with and without Nasal Polyps. J Allergy Clin Immunol Pract. 2017; 5: 1512-1516.

PubMed: https://pubmed.ncbi.nlm.nih.gov/28526278/

141. Kim DW, Cho SH. Emerging Endotypes of Chronic Rhinosinusitis and Its Application to Precision Medicine. Allergy Asthma Immunol Res. 2017; 9: 299-306

PubMed: https://pubmed.ncbi.nlm.nih.gov/28497916/

142. Klimek L, Bergmann KC, Biedermann T, Bousquet J, Hellings $P$, et al. Visual analogue scales (VAS): Measuring instruments for the documentation of symptoms and therapy monitoring in cases of allergic rhinitis in everyday health care: Position Paper of the German Society of Allergology (AeDA) and the German Society of Allergy and Clinical Immunology (DGAKI), ENT Section, in collaboration with the working group on Clinical Immunology, Allergology and Environmental Medicine of the German Society of Otorhinolaryngology, Head and Neck Surgery (DGHNOKHC). Allergo J Int. 2017; 26: 16-24. PubMed: https://pubmed.ncbi.nlm.nih.gov/28217433/ 